\title{
Lingwista wobec języka uczuć
}

\author{
Elżbieta Laskowska \\ Uniwersytet Kazimierza Wielkiego w Bydgoszczy \\ elaskows@ukw.edu.pl
}

\begin{abstract}
Streszczenie
Celem referatu jest zebranie dotychczasowych sposobów rozumienia zagadnienia języka uczuć przez lingwistów oraz zaproponowanie sposobu opisu języka uczuć. Zagadnienie to było przedmiotem zainteresowania takich badaczy jak Wierzbicka, Grabias, Nowakowska-Kempna, Awdiejew, Habrajska, Pajdzińska, Data. Biorac pod uwage poziomy języka, uwzględniane w gramatyce komunikacyjnej, autorka rozważa zjawiska nazywanie uczuć oraz ich wyrażania. Nazywanie mieści się na poziomie ideacyjnym, Wyrażanie - na poziomie interakcyjnym. Badajac wypowiedzi pod względem języka uczuć, zauważyć można, że nie zawsze tatwo jest wskazać granicę między wymienionymi poziomami. Trudności te zwiąane sa przede wszystkim $z$ dwiema kwestiami. Pierwsza z nich polega na wykorzystaniu nazw uczuć do ich wyrażania, mamy wtedy do czynienia z wyrażaniem uczuć za pomoca ich nazywania. Druga kwestia to emotywne nacechowania nazw uczuć albo té emotywne nazywanie reakcji mogacych świadczyć o uczuciu. Analiza wypowiedzi, zawierajacych nazywanie $i$ wyrażanie uczuć dowodzi, że $w$ różnych odmianach języka omawiane zjawisko występuje $w$ bardzo różnych zakresach i przejawia się bardzo zróżnicowanymi środkami językowymi).
\end{abstract}

Słowa kluczowe: język uczuć, gramatyka komunikacyjna, poziom ideacyjny, poziom interakcyjny, nacechowanie emocjonalne

Abstract

A Linguist in the Face of the Language of Feelings

The goal of the paper is collecting hitherto existing ways of understanding the concept of the language of feelings by linguists and suggesting a way of describing the language of feelings. This question was the subject interest of such researchers as Wierzbicka, Grabias, Nowakowska-Kempna, Awdiejew, Habrajska, Pajdzińska, and Data. Taking into account the levels of a language, included in communication grammar, the author considers naming of feelings and expressing them. The naming is contained in the ideation level, the expressing in the interaction level. Examining utterances with reference to the language of feelings one can notice that it is not easy to show a borderline between the mentioned levels. The difficulties are mainly connected with two questions. The first one consists in using the names of feelings for expressing them, in which the feelings are expressed by naming them. The second question 
is the emotive marking of the names of feelings or emotive naming of reactions which can manifest the feeling. The analysis the utterances including naming and expressing feelings proves that the phenomenon in question occurs in various scopes and manifest in diverse means of language.

Keywords: language of emotions, communication grammar, ideational level, interactional level, emotional load

\section{Język uczuć to nazywanie i wyrażanie uczuć}

Uczucie jest przeżyciem psychicznym w przeciwieństwie do doznania natury fizycznej, cielesnej (Por. Nowakowska-Kempna 1986: 15-16). Nie wyklucza to oczywiście jednoczesnego doznawania przez człowieka np. bólu głowy i zarazem zmartwienia $\mathrm{z}$ tego powodu. Można zresztą nazywać uczucia jako przeżycia psychiczne za pomocą porównań z doznaniami cielesnymi, np. Adam przeżywał coś, co można porównać do zanurzania się w lodowatej wodzie. Uczucia bywają opisywane w literaturze jako afekty, nastroje, usposobienia i postawy (Nowakowska-Kempna 1986: 14). Podziałem tym jednak nie będę się w dalszym ciągu zajmować, traktując uczucia jako przeżycia psychiczne, obok których może też człowiek przeżywać akty rozumu i woli.

Język dysponuje sporym zasobem środków, służących nazywaniu uczuć. Uczucia można bowiem nazywać, podobnie jak inne elementy rzeczywistości, przy czym kwestią do rozstrzygnięcia pozostaje typ sądu, w jakim orzekamy o uczuciu. Porównajmy:

Jan uśmiecha się do Marii.

Jan lubi Marię.

Pierwszy przykład stanowi sąd asertywny, jeśli przyjmiemy, że sądem asertywnym jest taki sąd, który można zweryfikować. Drugie zdanie nie da się zweryfikować, ponieważ doznawania uczucia przez kogoś drugiego nie można bezpośrednio obserwować. Przyjmijmy jednak, że istnieją pewne standardowe sposoby uzewnętrzniania uczuć. Pozwoliłoby to na zrozumienie zdania (2) następująco: 'Jan wobec Marii zachowuje się tak, jak zwykle zachowują się wobec innych osób ludzie, którzy te osoby lubią'. Jeśli tak potraktujemy orzekanie o cudzych uczuciach, to można przyjąć, że tego typu orzekanie jest sądem asertywnym ${ }^{1}$. Tak więc mówiąc o uczuciach, możemy odnieść się jedynie do zewnętrznych 
ich objawów, które są albo zgodne z rzeczywistymi przeżyciami obserwowanych osób, albo nie. Tej kwestii jednak nie sposób zbadać metodami lingwistycznymi.

Uczucia można uzewnętrzniać lub nie. Jednym ze sposobów uzewnętrzniania uczuć jest język. Wyrażanie uczuć jest drugim - obok nazywania - składnikiem języka uczuć. Nazywać można uczucia własne lub cudze, przeszłe, teraźniejsze i przyszłe. Wyrażać można jedynie uczucia własne, przeżywane tu i teraz. Oczywiście człowiek może wyrażać uczucia, których rzeczywiście nie doznaje, może też wyrażać co innego niż czuje. Tą kwestią jednak nie będę się zajmować.

\section{Uczucia można nazywać}

Jak pisze Data (Data 2000: 245-253), lingwiści częściej opisywali dotąd nazywanie uczuć w języku niż ich wyrażanie. Przyjmijmy, że nazywanie uczuć wiąże się z poziomem ideacyjnym (przedstawieniowym) wypowiedzi. Na tym poziomie użyte mogą być leksemy i frazeologizmy. Leksemy zostały opisane m.in. przez Nowakowską-Kempną (NowakowskaKempna 1986). Część zasobu frazeologicznego, odnoszącego się do uczuć, była tematem rozważań Gajdzińskiej (Pajdzińska 1999: 83-101). Badając środki językowe nazywające uczucia, możemy je dzielić na grupy semantyczne ${ }^{2}$ i badać relacje między tymi grupami, możemy też badać językowy obraz uczuć w polszczyźnie ${ }^{3}$. Można też wyliczyć typy środków językowych, za pomocą których nazywamy uczucia (Laskowska 2004 a: 213-221; Laskowska 2009: 351-361). Wymieńmy je kolejno.

2.1. Podstawowymi środkami są leksykalne i frazeologiczne nazwy uczuć, np. cieszyć się, radość, strach, bać się, tęsknota, czuć do kogoś miętę, komuś spada kamień z serca, mieć duszę na ramieniu. Podane przykłady mają wspólną cechę semantyczną: 'doznawać uczucia'. Inną cechę zawierają takie np. środki, jak martwić (kogoś), grać komuś na nerwach, cechą tą jest powodowanie uczucia: 'X wywołuje uczucie w $\mathrm{Y}$ '.

2.2. Kolejną grupą są środki, które mają nazwę uczucia wpisaną w strukturę semantyczną. Są to derywaty, utworzone od nazw uczuć, np. radośnie, smutny, żałosny, tęskny. Użycie tych środków wskazuje na uczucia w sposób pośredni, np. Jan spojrzał na Marię radośnie oznacza: 1. 'Jan spojrzał na Marię' 2. 'Jan [spoglądając na Marię], czuje radość'.

2.3. Uczucia mogą być implikowane przez użyte środki językowe, np. Chłopcy zachowywali sięagresywnie implikuje 'chłopcy doznawali uczucia złości i okazywali to swoim 
zachowaniem'; inny przykład: Ten aktor jest idolem Pawła zawiera implikację: 'Paweł doznaje wobec tego aktora uczuć sympatii i podziwu'.

2.4. Uczucia można nazywać pośrednio w jeszcze inny sposób: przez nazywanie reakcji mogących świadczyć o uczuciu. O niektórych uczuciach mogą świadczyć standardowe reakcje: śmiech - o radości, płacz - smutku, drżące ręce - o zdenerwowaniu itp. Na przykład: Jan uśmiechną się, Maria płacze, Po usłyszeniu wiadomości Ewa zbladła. To nie są opisy uczuć, ale reakcji fizycznych, które mogą, ale nie muszą świadczyć o doznawaniu uczuć. Takie reakcje mogą być też niestandardowe, np. Jerzy odwrócił oczy [kiedy usłyszał zarzuty], Anna wyszła z pokoju [kiedy ktoś zaczął ją krytykować], Piotr zaczął chodzić po mieszkaniu [kiedy ktoś poruszył drażniący go temat]. Na pograniczu środków nazywających reakcje mogące świadczyć o uczuciu i frazeologicznych środków nazywających uczucia stoją skonwencjonalizowane opisy omawianych reakcji, np. robić wielkie oczy, komuś pociemniało w oczach, ktoś zapomniat języka w gębie.

Nazywaniu elementów rzeczywistości towarzyszy niekiedy nacechowanie wartościującoemotywne, np. zamiast kobieta ktoś używa leksemu babsztyl. Nazwy uczuć też mogą być nacechowane. Na przykład:

Pawet nienawidzi ludzi, którzy mają inne niż on poglądy.

Barbara lekceważy swoje obowiązi.

Nadawca, nazywając za pomocą rozpatrywanych tu środków nazywa uczucia doznawane przez wskazane osoby, ale równocześnie wartościuje ich postawy emocjonalne: 'Paweł doznaje uczucia (przyjmuje postawę) nienawiści... [i to źle, ponieważ nienawiść wobec innych ludzi jest zła]', 'Barbara przyjmuje postawę lekceważenia... [i to źle, ponieważ lekceważenie czegoś jest złe']. Mamy tu zatem do czynienia z nazywaniem i wyrażaniem uczuć jednocześnie, przy czym nazywanie dotyczy uczuć cudzych, a wyrażanie - własnych. Można oczywiście wartościować uczucia własne, np. lekceważe twoje pogląy, w praktyce jednak takie wypowiedzi raczej nie powstają.

\section{Uczucia można wyrażać}

\subsection{Uczucia można wyrażać przez ich nazywanie}

Popatrzmy na przykłady:

1. Ciesze się, że cię widzę.

2. Martwi mnie mój stan zdrowia. 
3. Boję się o przyszłość mojego syna.

4. Zlości mnie jego zachowanie.

Użycie 1. osoby czasu teraźniejszego wskazuje na powstanie uczucia tu i teraz - pod wpływem właśnie zaistniałego stanu. Wskazanie na 1. osobę może mieć, rzecz jasna, inną postać. Na przykład:

5. Mam wielka przyjemność przywitać państwa na naszym spotkaniu.

6. To dla mnie wielka radość, że moge uczestniczyć w tej konferencji.

W wypowiedziach mogą się niekiedy pojawić nazwy uczuć w nie do końca jasnej funkcji. Na przykład:

7. Zachowanie Kowalskiego wzbudziło zażenowanie.

8. Postepowanie tej grupy oburza i zawstydza.

Wypowiedzi te można rozumieć dwojako:

7 a. Zachowanie Kowalskiego wzbudza we mnie zażenowanie.

8 a. Postepowanie tej grupy oburza mnie i zawstydza.

7 b. Zachowanie Kowalskiego wzbudza we wszystkich zażenowanie.

8 b. Postepowanie tej grupy wszystkich oburza i zawstydza.

Wypowiedzi 7 a i 8 a wyrażają uczucia, wypowiedzi 7 b i 8 b formalnie uczucia nazywają, jednakże funkcja tego typu wypowiedzi służy zwykle wartościowaniu i zarazem wyrażaniu uczuć nie wprost:

7 c. Zachowanie Kowalskiego wzbudza we wszystkich zażenowanie [co świadczy o tym, że zachowanie Kowalskiego jest złe],

8 c. Postępowanie tej grupy wszystkich oburza i zawstydza [co świadczy o tym, że postępowanie tej grupy jest złe].

\subsection{Wyrażaniu uczuć towarzyszy wartościowanie, a wartościowaniu towarzyszy} wyrażanie uczuć

Dlatego operuję określeniem funkcja wartościująco-emotywna, nie wprowadzając podziału wypowiedzi na takie, które stanowią wyrażanie sądów wartościujących oraz wyrażanie emocji. W sądzie wartościujących nadawca odwołuje się do normy, na przykład:

1. Pawet postapit uczciwie.

2. Obraz jest piękny. 


\section{Ewa zachowała się niegrzecznie.}

Przykład 1. odwołuje się do etycznej normy uczciwości, przykład 2. - do estetycznej normy piękna, przykład 3. - do utrwalonej tradycją normy obyczajowej. Uznajmy, że norma jest tu podstawowym motywem wartościowania, a uczucia są motywem towarzyszącym. Można jednak formułować wypowiedzi, gdzie albo ta hierarchia ulega zmianie, albo też uczucia zupełnie zacierają odwoływanie się do normy:

1 a. Pawet postapit wspaniale.

2 a. Obraz jest rewelacyjny.

3 a. Ewa zachowała się okropnie.

\subsection{Wyrażaniu uczuć mogą służyć wszystkie środki językowe}

\subsubsection{Wyrażać można czyste emocje}

Język dysponuje środkami, które są wyspecjalizowane w pełnieniu funkcji wartościującoemotywnej. Mogą to być:

- leksemy i frazemy ${ }^{4}$ na przykład: niestety, nareszcie, całe szczęście, niech to licho porwie, diabli nadali,

- morfemy słowotwórcze, np. kawka, pielęgniar[k]a, piśmidło, kotuś, handelek,

- morfemy fleksyjne, np. ministry, profesory, kulturalne ludzie,

- struktury leksykalno-składniowe, np. myślatem/am, że (padnę/nie wytrzymam/dostane zawatu...), Co za X (widok, człowiek, smak...), Zawsze ten X, Każdy tylko X,

- struktury leksykalno-prozodyczne; zaliczam tu konstrukcje z intonacją pytającą i wykrzyknikową, np. Dlaczego X, Po co X, Ile X, Gdzie X, Jak X.

Oprócz tych środków wyrażaniu uczuć mogą służyć same tylko cechy prozodyczne, a także organizacja tekstu. Oto przykład ostatniego ze sposobów wyrażania uczuć: Narada trwała dwie bite godziny; uczestnicy wyprawy do bieguna północnego mniej sa przewidujacy niż pani doktorowa (Kornel Makuszyński, Awantura o Basię). Wypowiedź ta (z kontekstu wiadomo, że chodzi o wyjazd dziewczynki do Warszawy) wyraża uczuciowy stosunek nadawcy do zachowania pani doktorowej za pomocą opisu jej zachowania z wykorzystaniem porównania.

\subsubsection{Wyrażanie uczuć może towarzyszyć nazywaniu obiektów}


Uczucia można też wyrażać za pomocą nacechowanych nazw obiektów, np. skandal, afera, palant, czupiradło, szwendać się, biadolić, ciagnąć trzy sroki za ogon. Tego typu środku (leksykalno-frazeologiczne) pełnią podwójną funkcję: odnoszą obiekt do rzeczywistości pozajęzykowej oraz wyrażają uczucie nadawcy wobec tego obiektu. Nazwy cech - wartości też służą wyrażaniu uczuć. Mogą one wskazywać na normę, np. porządny, słuszny, kulturalny albo też służyć tylko wyrażaniu emocji, np. świetny, beznadziejny, super. Ostatnia grupa zbliża się do tych środków, które wyrażają czyste emocje.

\subsection{Wyrażanie uczuć może towarzyszyć innym funkcjom interakcyjnym}

Emotywność może nakładać się na inne funkcje interakcyjne ${ }^{5}$. I tak na przykład potwierdzenia A jak! Żebyś wiedziat, Jasne! Ma się rozumieć! pełnią przede wszystkim funkcję informacyjno-weryfikacyjną, funkcją towarzyszącą jest tu funkcja emotywna, to znaczy, że nadawca wypowiedzi coś potwierdza i równocześnie wyraża emocje. Podobnie może być w przypadku zaprzeczeń, np. Ależ skąd! Nie będziesz mi tu bajek opowiadać! Zwariowałaś?! Nacechowane emocjonalnie może być także wyrażenie pewności, przypuszczenia, niewiedzy itp. np. nie ma cienia wątpliwości, aż strach pomyśleć, że ..., oby X, diabli wiedza. Nakłanianiu również może towarzyszyć wyrażanie emocji, np. no już! Hola, hola! Ani mi się waż! Co to to nie. Wyrażając emocje, nadawca wzmacnia nakłanianie. W podobny sposób - przez wyrażanie emocji - można też wzmocnić zobowiązanie, np. jak Boga (babcię) kocham! Mówię ci, słowo daję. Emotywność może się wyrażać niekiedy w operatorach organizacji tekstu, np. nie dosyć, że X, to jeszcze $Y$, dużo by tu mówić, i już, i koniec.

\subsection{Jakie kryteria mogą leżeć u podstaw opisu wyrażania uczuć?}

Funkcja wartościująco-emotywna przejawia się za pomocą operatorów emotywnych. W gramatyce komunikacyjnej przyjmuje się następujące kryteria opisu operatorów emotywnych:

- przyczyna stanu powodującego uczucie, tu są trzy możliwości: JA, TY,

- czynniki niezależne od JA i TY, w tym ON,

- korzystność lub niekorzystność tego stanu, 
- korzystność / niekorzystność dla JA, dla TY lub dla ON (Awdiejew, 2004: 123-126),

- izomorficzność lub brak izomorficzności uczucia do stanu rzeczy.

Biorąc pod uwagę rożne możliwości, Aleksy Awdiejew wyróżnia 36 grup operatorów emotywnych (Awdiejew, 2004). Obserwacja tych operatorów poucza, że jeden operator może „obsługiwać” różne grupy. I tak np. operator chwała Bogu może być użyty wobec stanu spowodowanego przez nadawcę, odbiorcę lub czynnik niezależny, może też dotyczyć nadawcy, odbiorcy lub trzeciej osoby. Na przykład:

1. - Zdateś egzamin?

- Tak. Chwała Bogu!

2. - Udało mi się znaleźć klucze

- Chwata Bogu!

3. - Przestało padać.

- Chwala Bogu!

W pierwszym przykładzie przyczyną stanu powodującego emocje jest działanie nadawcy, a stan dotyczy odbiorcy wypowiedzi. Drugi przykład pokazuje stan spowodowany przez odbiorcę i odbiorcy też dotyczy. Trzecia wypowiedź wskazuje na przyczynę niezależną od nadawcy i odbiorcy, a stan budzący emocje dotyczy nadawcy (i zapewne odbiorcy także). Omawiany operator jest nacechowany pozytywnie i standardowo używa się go w sytuacji, gdy mowa jest o stanie korzystnym, choć możliwe jest też użycie nieizomorficzne, np.

4. - Zieliński złamat nogę i poszedt do szpitala.

- Chwała Bogu. Nie będzie nam przeszkadzat w budowie garażu.

Niektóre operatory mają nieizomorficzność wpisaną w strukturę semantyczną, np. trafiło ci/mi/ jemu się jak ślepej kurze ziarno wyraża negatywne uczucie z powodu korzystnego stanu dla nadawcy, odbiorcy lub osoby trzeciej. Obserwacja wypowiedzi potocznych pozwoliła na stwierdzenie, że możliwe jest wyrażanie uczuć we wszystkich wskazanych przez Aleksego 
Awdiejewa grupach (Laskowska, 2009). W wypowiedziach publicznych niektóre z grup nie wystąpiły. Na przykład w wypowiedziach parlamentarnych nie odnotowano na przykład wyrażania pozytywnych uczuć z powodów niekorzystnego stanu dla odbiorcy (Laskowska, 2004 a; Laskowska 2004 b: 141-143).

\subsection{Jakimi terminami dobrze jest posługiwać się przy opisie języka uczuć?}

Podstawowym terminem, koniecznym w opisie języka uczuć, jest emotywność, rozumiana jako cecha wypowiedzi o funkcji wartościująco-emotywnej. Warto by odróżnić to określenie od określenia emocjonalność. Zjawisko nazwane w ten sposób odnosi się do pewnego, właściwego dla niektórych osób sposobu mówienia o rzeczywistości. Sposób ten przejawia się przede wszystkim w barwie głosu i wykorzystaniu innych cech prozodycznych, które bardziej znamionują cechy osobowości człowieka niż jego stosunek uczuciowy do treści, o których mówi. Nie wyklucza to oczywiście występowania emotywności i emocjonalności w jednej wypowiedzi. Są jednak ludzie, którym emocjonalność jest obca, co nie znaczy, że ich wypowiedzi nigdy nie pełnią funkcji wartościująco-emotywnej. Takiej możliwości nie ma. Świat człowieka jest światem uczuć i wartości, co znajduje odzwierciedlenie w przekazach językowych.

\section{Przypisy}

${ }^{1}$ Prof. Grażyna Habrajska powiedziała mi kiedyś w dyskusji, że sądy, w których orzeka się o cudzych uczuciach, należałoby potraktować jako sądy modalne, wyrażające przypuszczenie.

${ }^{2}$ Uczyniła to Nowakowska-Kempna (1986), dzieląc uczucia na afekty i postawy i wyodrębniając w ich ramach mniejsze jeszcze grupy. Każdej z grup można przypisać znak: pozytywny lub negatywny, jedynie zdziwieniu i ciekawości nie przypisuje autorka żadnego znaku.

${ }^{3}$ Co zrobiła Pajdzińska, 1999.

${ }^{4}$ Frazemami nazywam za - Aleksym Awdiejewem - nazywam jednostki ponadjednoelementowe o funkcji innej niż funkcja ideacyjna, a zatem pełniące funkcję interakcyjną i/lub metadyskursywny. Zob. Awdiejew, $2004: 97$.

5 W mojej pracy (Laskowska, 2004 b) wyróżniam trzy funkcje interakcyjne: informacyjno-weryfikacyjną, wartościująco-emotywną oraz funkcję działania. Wzoruję się na rozróżnieniu Aleksego Awdiejewa, u niego jednak wymienione są następujące funkcje: modalne, modalno-syntagmatyczne, emotywno-oceniające oraz działania (Awdiejew 2004: 83-123). 


\section{Źródło}

Tekst ten został po raz pierwszy opublikowany w roku $2012 \mathrm{w}$ tomie Termin w językoznawstwie, pod redakcją Doroty Brzozowskiej i Władysława Chłopickiego, Język a komunikacja 31, Kraków: Tertium; 151-159.

\section{Bibliografia}

Awdiejew, Aleksy (2004) Gramatyka interakcji werbalnej. Kraków: Wydawnictwo Uniwersytetu Jagiellońskiego.

Data, Krystyna (2000) „W jaki sposób językoznawcy opisują emocje?”. [W:] Iwona Nowakowska-Kempna, Anna Dąbrowska, Janusz Anusiewicz (red.) Język a kultura, tom 14. Uczucia w języku i tekście. Wrocław: Wydawnictwo Uniwersytetu Wrocławskiego; 245-252.

Laskowska, Elżbieta (2004 a) „Uczucia w języku”. [W:] Leszek Bednarczuk, Edward Stachurski, Tadeusz Szymański (red.) Annales Academiae Paedagogicae Cracovienses. Studia Liguistica II. Kraków; 213-221.

Laskowska, Elżbieta (2004 b) Dyskurs parlamentarny w ujęciu komunikacyjnym. Bydgoszcz: Wydawnictwo Akademii Bydgoskiej im. Kazimierza Wielkiego.

Laskowska, Elżbieta (2009) „Nazywanie i wyrażanie uczuć w języku”. [W:] Magdalena Hawrysz (red.) Zielonogórskie seminaria językoznawcze. Zielona Góra: Oficyna Wydawnicza UZ; 351-361.

Nowakowska-Kempna, Iwona (1986). Konstrukcje zdaniowe z leksykalnymi wykladnikami predykatów uczuć. Katowice: Uniwersytet Śląski.

Pajdzińska, Anna (1999) „Jak mówimy o uczuciach? Poprzez analizę frazeologizmów do językowego obrazu świata”. [W:] Jerzy Bartmiński (red.) Językowy obraz świata. Lublin: Wydawnictwo UMCS; 83-101. 